\title{
Dynamic tensile testing for determining the stress-strain curve at different
}

\section{strain rate}

\author{
A. Mansilla*, A. Regidor*, D. García* and A. Negro*
}

\begin{abstract}
A detailed discussion of high strain-rate tensile testing is presented. A comparative analysis of different ways to measure stress and strain is made. The experimental stress-strain curves have been suitably interpreted to distinguish between the real behaviour of the material and the influence of the testing methodology itself. A special two sections flat specimen design was performed through FEA computer modelling. The mechanical properties as function of strain rate were experimentally obtained and the measurement system limitations were evaluated. The strain rate material law was simulated and a good correlation between experimental and simulated engineering stress-strain curves was reached.
\end{abstract}

Keywords Tensile testing. Stress-strain curves. Strain rate. FEA computer modelling. Testing methodology.

\section{Ensayo dinámico de tracción para la determinación de la curva esfuerzo-deformación a distintas velocidades de deformación}

Resumen

\begin{abstract}
Se presenta un estudio detallado del ensayo de tracción a alta velocidad de deformación. Se compararon dos formas diferentes de medir, tanto esfuerzo como deformación. Se interpretaron cuidadosamente las curvas esfuerzo-deformación para distinguir entre el comportamiento real del material y la influencia de la propia metodología de ensayo. Se diseñó una probeta plana especial de dos secciones mediante simulación por elementos finitos. Se obtuvieron, experimentalmente, las propiedades mecánicas como función de la velocidad de deformación y se evaluaron las limitaciones de los sistemas de medida. La ley del material, dependiente de la velocidad de deformación, se simuló, obteniéndose una buena correlación entre las curvas esfuerzo-deformación ingenieril experimental y simulada.
\end{abstract}

Palabras clave Ensayo de tracción. Curva esfuerzo-deformación. Velocidad de deformación. Simulación por elementos finitos. Metodología de ensayo.

\section{INTRODUCTION}

The design of crashworthiness structures is being currently improved by means of Finite Element Analysis (FEA) computational methods.

The strain-rate material law is fundamental to obtain good results in the simulation stage. Although there are some databases of strain-rate experimental curves of metallic alloys specially, very little detailed information is given about the methodology used to obtain the stress-strain curves. Actually, there are not standards to perform this kind of tests.

\section{EXPERIMENTAL}

A high speed servo-hydraulic testing machine MTS 831.59 was used. The capacity of the machine is $25 \mathrm{kN}$ and it is able to move its actuator up to $14 \mathrm{~m} / \mathrm{s}$. The signals were registered by means of SAN-EI 2102 DC Conditioners, a ROHRER

(*) CIDAUT (Centre For Automotive Research And Development). Parque Tecnológico de Boecillo Parcela, 209.47151 Boecillo, Valladolid (España). 
DMS805B Conditioner (frequency response $500 \mathrm{kHz}$ ), a KISTLER 5011 Conditioner and a NICOLET MULTIPRO Acquisition System (sampling frequency $1 \mathrm{MHz}$ ).

\subsection{Specimen description}

In order to develop a tensile testing methodology for flat specimens, a special specimen design was performed through FEA computer modelling. The goal was to measure stress and strain directly over the specimen by using strain gauges. The design was focused to improve the behaviour of the specimen working under uniaxial dynamic loads. This study was made with PAM-CRASH software.

As shown in figure 1, there are two sections in the specimen: the dynamometer section and the extensometer section. The stress measurement is carried out in the widest one (dynamometer section). Two strain gauges (CEA-06-125UN-120 Measurement Group) are bound inside this zone, one each side to compensate bending effects. In a similar way, strain measurement is made in the thinnest zone (extensometer section), high elongation strain gauges (EP-08-250BG-120 Measurement Group) are bound.

The material never reaches yielding in the dynamometer section, so the linear-elastic behaviour of the material in this region allows Hooke's Law to be applied and obtain stress by using strain gauges.
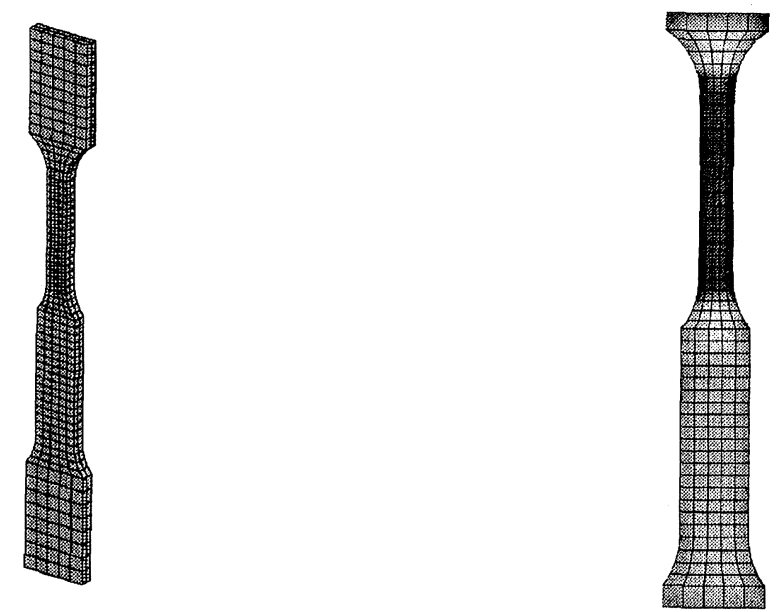

Figure 1. High-rate tensile testing specimen.

Figura 1. Probeta para ensayo de alta velocidad de deformación.

\subsection{Dynamic tensile testing system description}

The stress measurement was carried out by means of two systems: a piezoelectric load washer KISTLER 9041-A and strain gauges bound on the specimen surface. The strain gauges were quasistatically calibrated as a force transducer.

The strain measurement was made in two different ways: a high-speed digital video camera KODAK HS45-40 (40500fps) and high elongation strain gauges placed in the extensometer section of the specimen.

The actuator movement was controlled by a LVDT transducer. To obtain a constant strain rate during the test, a slack adapter was assembled between the actuator and the tensile grips. The actuator reaches the expected speed before the contact in the slack adapter is produced. A damper material was introduced inside the slack to avoid undesirable metallic contact.

\section{RESULTS}

An aluminium alloy $6082 \mathrm{~T} 6$ was used for this study. The material was tested at $5 \mathrm{~mm} / \mathrm{min}$ (quasistatic), $1 \mathrm{~m} / \mathrm{s}$ and $7.8 \mathrm{~m} / \mathrm{s}$.

The material law depending on the strain rate is shown in figure 2.

Both quasi-static $(5 \mathrm{~mm} / \mathrm{min})$ and dynamic $(1 \mathrm{~m} / \mathrm{s})$ simulations were performed. An adjustment of the stress-time and strain-time curves was carried out and a good correlation between experimental and simulated stress-strain curves was achieved.

The figures 3 and 4 show the quasi-static correlation. As can be seen, the results seem to be

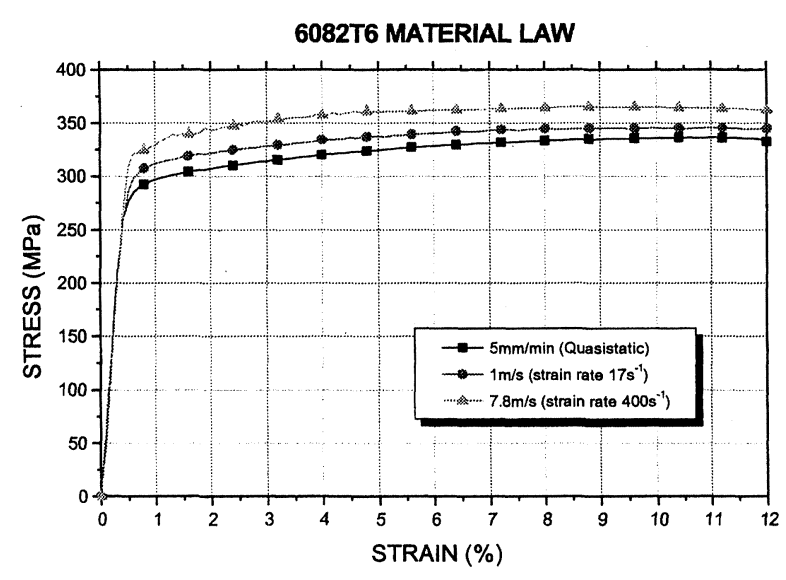

Figure 2. $6082 T 6$ material law.

Figura 2. Ley de material 6082T6.

Rev. Metal. Madrid 37 (2001) 


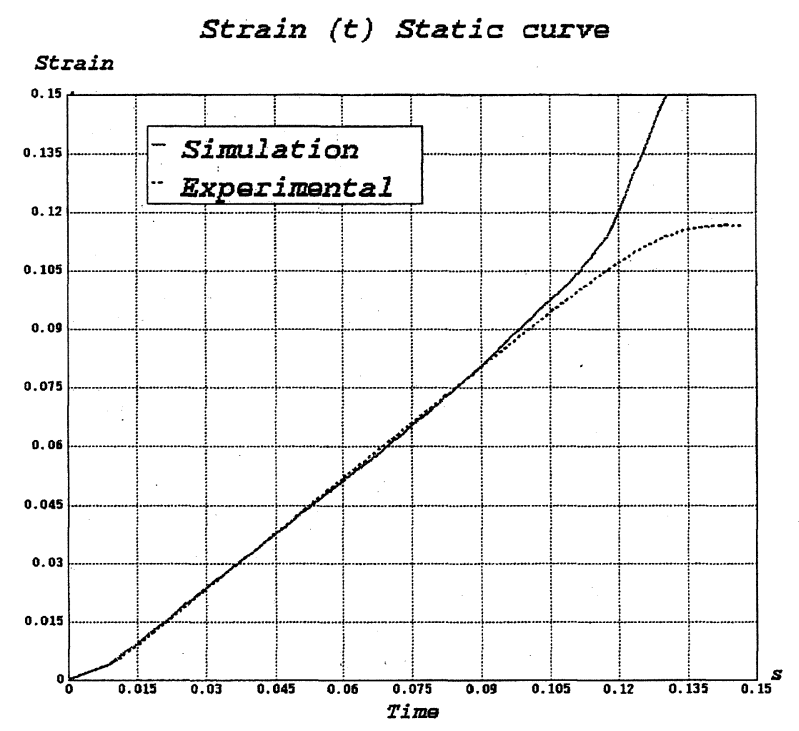

Figure 3. Strain-time curve $(5 \mathrm{~mm} / \mathrm{min})$.

Figura 3. Curva deformación-tiempo $(5 \mathrm{~mm} / \mathrm{min})$.

Stress (t) Static curve

Stress (MPa)

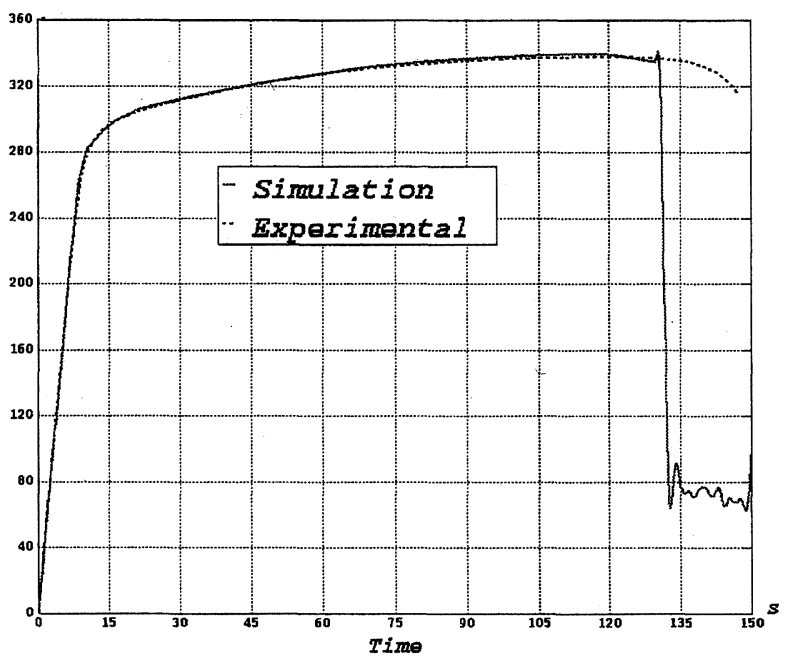

Figure 4. Stress-time curve $(5 \mathrm{~mm} / \mathrm{min})$.

Figura 4. Curva tensión-tiempo $(5 \mathrm{~mm} / \mathrm{min})$.

very accurate, and the correlation is fine until fracture point, which is very difficult to predict.

Once an accurate stress-strain curve for the quasi-static material characterization is obtained, it is possible to proceed with dynamic simulation.

To verify the simulation, three curves must be taken into account: stress-time, strain-time and stress-strain.

The stress-time curve has mainly to do with the strain-rate behaviour of the material. There are

several models available, the Johnson-Cook Law was finally chosen:

$$
\sigma(\varepsilon, \dot{\varepsilon})=\sigma_{0}(\varepsilon)\left[1+\frac{1}{p} \ln \left(\max \left(\frac{\dot{\varepsilon}}{D}, 1\right)\right)\right]
$$

where $\sigma_{0}(\varepsilon)$ is the quasi-static stress-strain curve, and $p$ and $D$ are the dynamic parameters that must be adjusted.

The stress-time and strain-time curves cannot be tuned separately, because they depend on each other. It is a process and one curve must be adjusted without distorting the previously correlated one.

As the other two curves were well correlated, an accurate stress-strain curve was reached. The results are shown in figure 5.

Two different gauge positions were used, figure 6. Gauge 1 was placed exactly where the specimen broke, while gauge 2 was slightly below. The main differences come when the specimen breaks: strain measured on gauge 1 continues growing, while gauge 2 stops and slightly decreases.

Figure 7 shows a good correlation, especially at lower strains. When the test specimen is about to break, the strain rate becomes higher and the amplification given by the Johnson-Cook law makes our curve grow more than it really does. This effect continues until the specimen breaks.

\section{DISCUSSION}

\subsection{Measurement of stress}

Two strain gauges were placed in the dynamometer section, one an each side, so that the bending

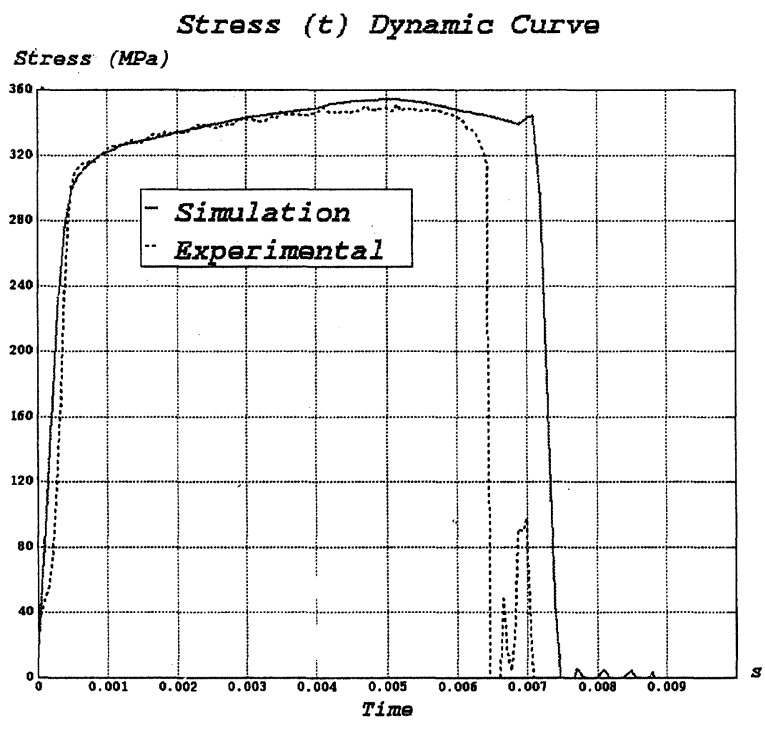

Figure 5. Stress-time curve $(1 \mathrm{~m} / \mathrm{s})$.

Figura 5. Curva tensión-tiempo $(1 \mathrm{~m} / \mathrm{s})$. 


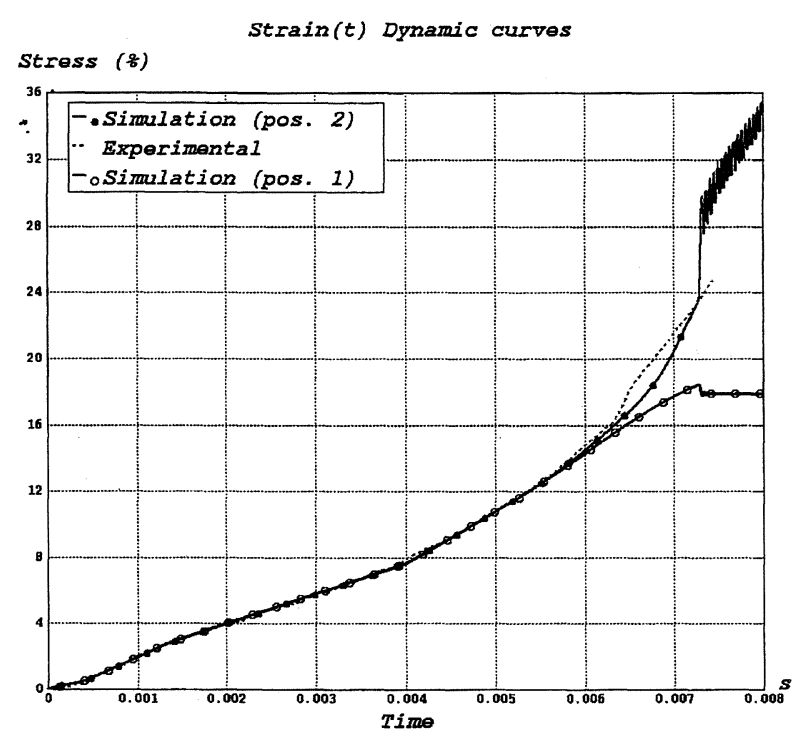

Figure 6. Strain-time curve $(1 \mathrm{~m} / \mathrm{s})$.

Figura 6. Curva deformación-tiempo $(1 \mathrm{~m} / \mathrm{s})$.

effects were eliminated. The bending was corrected by calculating the averaged strain between both strain gauges. The result can be seen in figure 8 .

The load washer measurement limitations are shown in figure 9. There are problems due to the ringing of this transducer. The load washer doesn't show the real material behaviour because the inertial effects during the dynamic test produce an error in the measurement ${ }^{[1]}$. The actual stress-time curve is properly measured by the strain gauges, while the load washer curve is restricted by the frequency response of the mechanical assembly $(2.8 \mathrm{kHz})$. It is recommended in order to obtain a reliable measurement that at least 5 oscillations are registered in the transducer signal during the rise time ${ }^{[2]}$. This

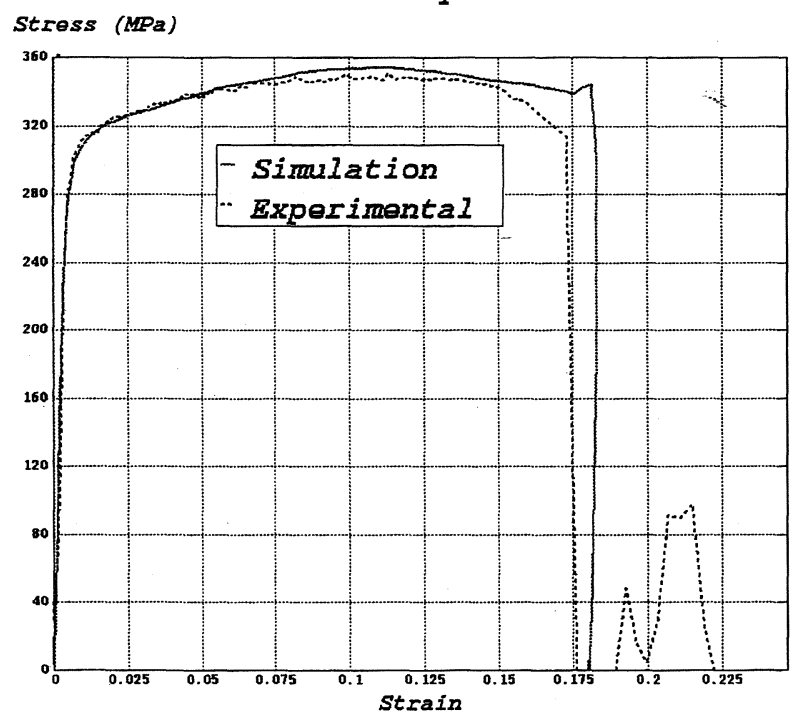

Figure 7. Stress-Strain curve $(1 \mathrm{~m} / \mathrm{s})$.

Figura 7. Curva tensión-deformación $(1 \mathrm{~m} / \mathrm{s})$.

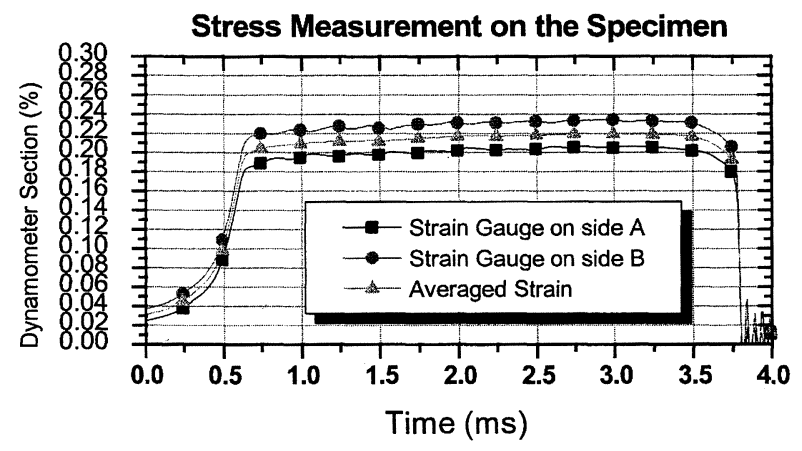

Figure 8. Bending effects compensation.

Figura 8. Compensación de efecto de flexión.
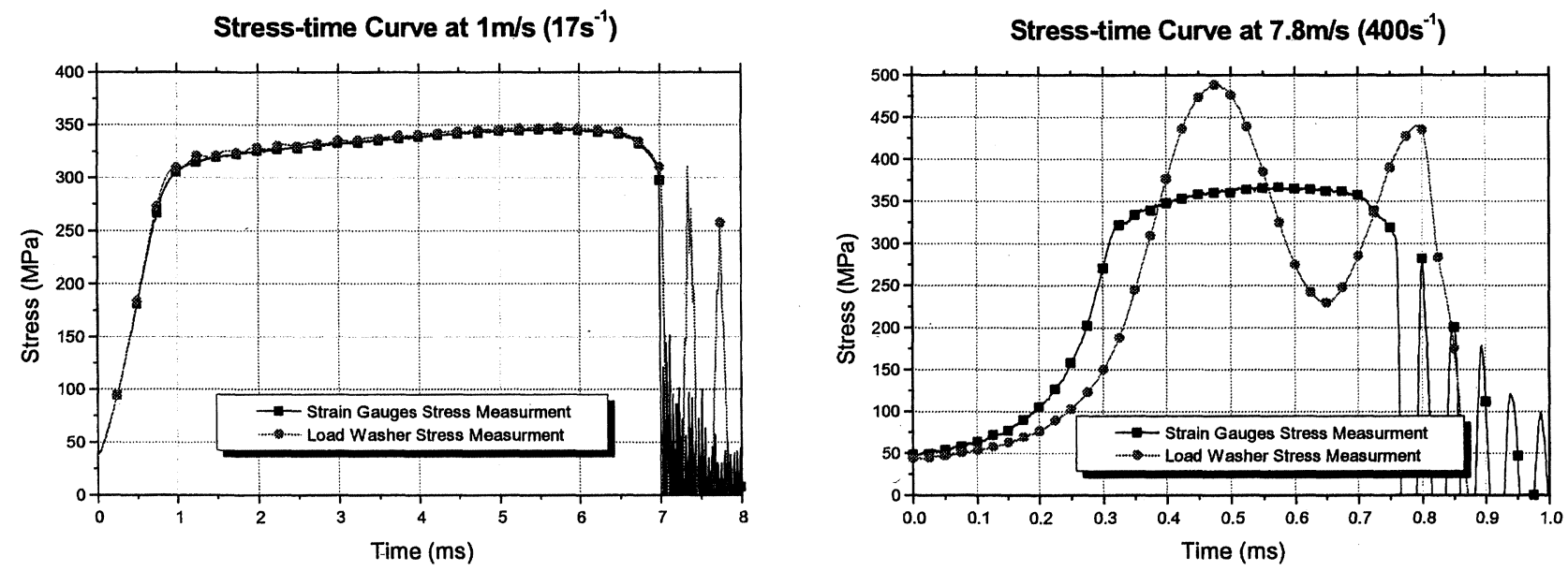

Figure 9. Load washer measurement limitations.

Figura 9. Limitaciones en la medida de carga. 
means a $3 \%$ error during the initial ramp and a $6 \%$ error in the subsequent horizontal zone.

In the test performed at $1 \mathrm{~m} / \mathrm{s}$, it is seen how the elastic region up to yielding can be measured with the load washer. However, in the test at $7.8 \mathrm{~m} / \mathrm{s}$, neither the elastic region nor the plastic region can be measured with the load washer.

The strain rate limit depends on the tested material and can be increased by improving the resonance frequency of the load cell and optimising the damper material.

\subsection{Measurement of strain}

The strain cannot be calculated with sufficient accuracy from crosshead movement because, in tensile testing, it is not the best way to obtain the Young Modulus nor the Yield Point. Besides, in this assembly there is a relative displacement between actuator and grip. So that direct measurements on the specimen itself are required.

The strain was measured with a digital camera and strain gauges. Both complement each other.

The high elongation strain gauges cover the elastic behaviour and the yielding up to approximately a $12 \%$ in dynamic tests. This transducer allows an accurate Young Modulus and Yield Point to be obtained. To use high elongation strain gauges involves applying special corrections to the gauge measurement. It is necessary to take into account the errors in the Wheatstone bridge linearity ${ }^{[3]}$ and the gage factor variation ${ }^{[4]}$.

To measure strain higher than $10 \%$ a KODAK digital video camera is used. The camera does not measure properly low elongation. So it is not able to determine accurate neither Young Modulus nor Yield Point, but it works fine above $1 \%$.

It could be seen that the corrections applied to the high elongation strain gauge are good. The digital camera and the strain gauge measure the same up to necking. Afterwards, the camera measures higher elongation because the neck is formed inside the camera marks.

\section{CONCLUSION}

The limits of the measurement systems have been studied and analysed:

- Although the load washer is not as good measurement system as the strain gauges, both are suitable systems for stress measurement.

- The high-speed digital video camera and the high elongation strain gauges complement each other for strain measuring.

A procedure to obtain the experimental high strain-rate material law has been established.

The experimental results have been successfully implemented in dynamic simulation software's.

\section{Acknowledgements}

This work was supported by the CICYT (Comisión Interministerial de Ciencia y Tecnología).

\section{REFERENCES}

[1] D.R. Ireland, Procedures and Problems Associated with Reliable Control of the Instrumented Impac Test, Intrumentated Impact Testing, ASTM STP 563.

[2] A.S. KoBAYASHI, Handbook on Experimental Mechanics, SEM, Vch.

[3] Error Due to Wheatstone Bridge Nonlinearity, TN-507 Measurements Group.

[4] High-Elongation Strain Measurements, TT-605 Measurements Group. 